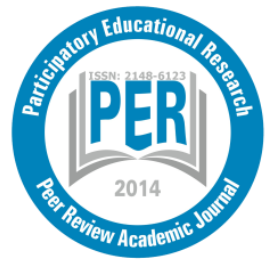

Participatory Educational Research (PER)

Vol.9(3), pp. 344-361, May 2022

Available online at http://www.perjournal.com

ISSN: 2148-6123

http://dx.doi.org/10.17275/per.22.70.9.3

\title{
Are Dissertations Trustworthy Enough? The case of Turkish Ph.D. Dissertations on Social Studies Education
}

\author{
Önder ERYILMAZ* \\ Department of Turkish and Social Sciences Education, Amasya University, Amasya, Turkey \\ ORCID: 0000-0002-4962-889X
}

\begin{tabular}{ll}
\hline \hline Article history & Although there is an increasing number of studies concentrating upon \\
Received: & education, some researchers have revealed that most studies, including \\
& qualitative studies in education, have methodological issues. One of the \\
Received in revised form: & most common mistakes and neglected issues in qualitative studies is not \\
01.12 .2021 & to ensure the trustworthiness of the research, which indeed is an \\
& important component for the rigor of the study. The main purpose of this \\
Accepted: & study is to examine how researchers ensure the trustworthiness of Ph.D. \\
06.12 .2021 & dissertations in social studies education. Document analysis was \\
Key words: & employed in the study. I examined 197 Ph.D. dissertations belonging to \\
\hline Trustworthiness, & years 2002 and 2020 as well as to the field of social studies education \\
Rigor, & which were obtained from the National Dissertation Center of Turkish \\
Qualitative research, & Higher Education Council. I used the deductive coding and analysis \\
apcial studies education. & approach in order to examine dissertations. The study results revealed \\
& that no trustworthiness strategy was used or reported in nearly half of \\
& Ph.D. dissertations that were conducted in the field of social studies \\
& education. Researchers mostly preferred to use validity and reliability \\
& terms, which are highly criticized by some scholars as to the paradigm of \\
& qualitative orientations. Besides, while some trustworthiness strategies \\
such as peer debriefing and external audit were mainly used, others such \\
as negative case analysis and stepwise replication were not used or \\
reported in any dissertation. Some recommendations were made \\
considering the study results and discussions at the end of the study.
\end{tabular}

\section{Introduction}

In the last decades, there have been many publications, including articles and dissertations in the education field (Huang et al., 2020). Undoubtedly, one of the main reasons for the rise in educational research is the considerable interest in the qualitative research methods in social sciences, especially in the second half of the 19th century (Cooley, 2013). Besides, the interest in mixed-method research that qualitative and quantitative research methods are used simultaneously also increased that number (Şahin and Öztürk, 2019). Although there is an increasing number of studies concentrating upon education, some researchers have revealed that most studies, including qualitative studies in education, have

* Correspondency: onder.eryilmaz@amasya.edu.tr 
analytical and interpretational issues (Onwuegbuzie and Daniel, 2003). One of the most common mistakes and neglected issues in qualitative studies is not to ensure the trustworthiness of the research, which is very important for the rigor of the study (Gunawan, 2015; Twining et al.,2017).

\section{Trustworthiness}

One of the critical elements that distinguish scientific research from ordinary research is rigor, as it ensures scientific consistency from the research questions to the conclusion. Trustworthiness plays the most critical role in the rigor of qualitative research studies (Amankwaa, 2016).

The term trustworthiness is used predominantly by constructivism, social constructivism, and interpretivism, which refers to evaluating a study's quality (O'Donoghue, 2007; Patton, 2002). The main aim of trustworthiness is to support the research argument of which findings are "worth" paying attention to (Elo et al., 2014; Lincoln and Guba, 1985). Trustworthiness does not occur inherently, but it is derived from rigorous scholarship that ensures that the findings reflect participants' intentions as closely as possible (Lietz, Langer and Furman, 2006; Murphy and Yielder, 2010). On the other hand, trustworthiness convinces readers how the data analysis and findings are worthy and trusty (Law, 2002, as cited in Curtin and Fossey, 2007).

The trustworthiness term was proposed in "Criteria for assessing the trustworthiness of naturalistic inquiries" by Guba in 1981 when positivist scholars severely criticized qualitative studies in terms of validity and reliability. Therefore, Guba proposed several strategies characterized by four criteria of "trustworthiness" (i.e., credibility, transferability, dependability, and confirmability) corresponding to the internal validity, external validity, reliability, and objectivity which were acknowledged as essential for the rigor of quantitative studies by the positivists (Guba, 1981). He asserted that qualitative researchers should use these strategies and criteria to establish the "trustworthiness" of a study. A few years later, Lincoln and Guba (1986) systematically explained those trustworthiness strategies and criteria in their book "Naturalistic Inquiry." Since then, "trustworthiness" term has been widely accepted as the key to ensuring the study's rigor (Creswell, 1998; Morse, 2015; Nowell et al., 2017; Shenton, 2004). Trustworthiness strategies and related criteria are shown in Table 1. 
Table 1. Trustworthiness strategies and criteria

\begin{tabular}{ll}
\hline Trustworthiness Criteria & Trustworthiness Strategies \\
\hline \multirow{2}{*}{ Credibility } & Prolonged Engagement \\
& Persistent Observation \\
& Peer Debriefing \\
& Member Checking \\
& Referential Adequacy \\
& Negative Case Analysis \\
& Reflexivity \\
Transferability & Triangulation \\
& Thick Description \\
& Thick Descriptive Data \\
& Reflexivity \\
& Purposeful Sampling \\
& Audit Trail \\
Dependability & External Audit \\
& Stepwise Replication \\
& Reflexivity \\
& Overlap methods \\
Confirmability & Triangulation \\
& Audit Trail \\
& External Audit \\
& Reflexivity \\
&
\end{tabular}

(Guba, 1981; Lincoln and Guba, 1985).

As shown in Table 1, several trustworthiness strategies and criteria were proposed for establishing trustworthiness in qualitative studies. Trustworthiness strategies proposed by Guba (1981) and Lincoln and Guba (1985) are explained below:

Prolonged Engagement: Researchers spend a long time in the research site to collect enough data, determine and overcome participants' prejudice towards themselves and establish a trustful and warm relationship with them.

Persistent Observation: Researchers try to observe the research site as much as possible. This strategy also enables researchers to understand and explain the study phenomenon or case deeply.

Peer Debriefing: Researchers give some of the raw data to an independent researcher experienced in qualitative data analysis for analysis. At the end of the data analysis, both researchers compare and discuss the results in the light of the research question until they agree on the findings. This strategy helps researchers recognize the overlooked points and allows the reanalysis of the data with new insights.

Member Checking: Researchers show their raw data such as interview documents and their analysis to check whether the researcher understands participants correctly. This strategy 
prevents misunderstandings and research bias.

Referential Adequacy Materials: Like action research, researchers record their data collection and analysis process in a journal or a videotape. Referential adequacy materials enable the researcher to evaluate the research and make a self-assessment from a different perspective when they are out of the research site.

Negative Case Analysis: This strategy cannot be used in all circumstances. Researchers can only use this strategy if they have atypic participants, so-called "negative case" in the study group. If there is a negative case (atypic participant) in the study group, the researcher can evaluate their findings by comparing negative cases with other participants. In other words, this strategy enables researchers to test their findings by comparing atypic and other participants.

Triangulation: Triangulation is one of the most effective trustworthiness strategies. Researchers can cross-check the data and interpretations by triangulating data sources, methods, analysts, or theories.

Audit Trail: Researchers systematically document all the procedures, including writing the research question, data collection, data analysis, and interpretations to show and explain the rigor of the study. In other words, it is the record of the whole study from the beginning to the end. This strategy also allows readers to understand how the research is carried out step by step.

External Audit: Researchers sometimes focus on the specific aspects of the study data and analysis, and they might miss possible important data and interpretations. Researchers could consult external audits to prevent it. An independent specialist or a group of experts such as a monitoring committee criticize and evaluate the study from a different perspective in the external audit strategy. Consequently, this trustworthiness strategy helps reducing possible fails, especially in the data analysis and interpretation process.

Stepwise Replication: This strategy requires more than one researcher divided into two inquiry groups to deal with data analysis separately. Groups try to analyze the data independently and compare and discuss about the findings between each other until building consensus.

Overlap methods: This strategy is a kind of triangulation method. Two or more methods are applied to compensate for the weaknesses of others. Overlap methods strategy helps researchers to collect comprehensive and consistent data.

Reflexivity: In this strategy, researchers write reflections in every step of the study, which helps them see how they collect, analyze and interpret the data. It also helps researchers understand what they thought and how they felt during the study. Researchers usually use "researcher journal" to reflect their thoughts about the study.

\section{Research Problem}

The interest in qualitative research methods has been increasing in Turkey, just like in the world day by day, and this interest shows itself in the number of publications (Saban et al., 2010). The situation about the qualitative research methods and the importance of trustworthiness that one of the most neglected components in qualitative educational research 
made me wonder how researchers ensured trustworthiness in dissertations in social studies education, my study of expertise.

The roots of social studies education in Turkey dates back to the late twentieth century. However, the social studies term was firstly used in 1968 with the educational reform (Akpınar and Kaymakçı, 2012; Çayır and Gürkaynak, 2007). Although it was abolished from the curriculum for several reasons in the 1980s, it was included in the elementary school curriculums in 1998 (Öztürk, 2012). As of 1998, the research in social studies education accelerated in Turkey (Sağdıç, 2019). Because Social Studies Education Departments were established in universities, and social studies drew the attention of researchers who not only study on social studies education but also study on other related fields such as curriculum and instruction in Turkey. Today, there are around 2600 dissertations on social studies education in the National Dissertation Center of the Turkish Higher Education Council Database. Considering this growth on the literature, I attempted to evaluate them in terms of the trustworthiness in qualitative research, one of the critical elements for the rigor of a study.

In the literature, several studies examined dissertations in social studies education by particular variables such as year, method, study group, and topic not only in Turkey (e.g., Canbulat, Görkem, and Sipahi, 2016; Dilek, Baysan and Öztürk, 2018; Duman and İnel, 2019; Haçat and Demir, 2018; Tarman, Acun and Yüksel, 2010; Şahin, Yıldı, and Duman, 2011) but also in Canada (Dhand, 1984, 1988) and the United States (Chapin, 1974; Gross and De La Cruz, 1971; Hepburn and Dahler, 1985; Saxe, Jackson and Mraz, 1994; Wrubel and Ratliff, 1978). There are also some review studies conducted explicitly on citizenship (Kayaalp and Karameşe, 2020), concepts (Karakuş, 2020), literacy skills (Güleç and Hüdavendigar, 2020), and geography (Öner and Öner, 2017). Although the number of dissertations using qualitative or mixed method approaches in social studies education has increased in Turkey in the last decades, no research specifically focuses on how researchers ensure the rigor or trustworthiness of their studies.

Considering the current findings and the literature gap, I examined trustworthiness strategies in the social studies Ph.D. dissertations. This study would be essential to provide a broad perspective and determine common mistakes about the rigor of dissertations in social studies education and educational research in Turkey. Besides, I believe the study results would help graduate students and future researchers who plan to employ qualitative research methods in their dissertation.

\section{Method}

I employed the document analysis method to analyze dissertations. According to Bowen (2009), document analysis is a systematic procedure for reviewing, interpreting, and evaluating documents. In this research, I systematically analyzed, evaluated, and interpreted dissertations on social studies education in Turkey in terms of trustworthiness strategies.

\section{Documents}

In this research, I analyzed 197 social studies education doctoral dissertation where qualitative and mixed research methods were employed in terms of trustworthiness strategies which was proposed and conceptualized by Guba (1981). I preferred to analyze only Ph.D. dissertations for several reasons. First of all, articles, papers, or reports have word limitations, and researchers may not give priority to report the study's trustworthiness in these types of 
publications. Secondly, it is assumed that Ph.D. students and their supervisors are experienced enough in conducting and reporting research. Because students are expected to complete a master thesis before a Ph.D. dissertation, and a Ph.D. supervisor must officially consult at least a master thesis before consulting a Ph.D. Thirdly, the Ph.D. process has several essential steps that Ph.D. candidates and their supervisors have to convince the Ph.D. guidance committee and defense committee. Therefore, I only analyzed Ph.D. dissertations on social studies education in which researchers employed qualitative and mixed-method research methods. I showed the PRISMA about how I obtained dissertations from the National Thesis Center of the Turkish Higher Education Council in Figure 1.

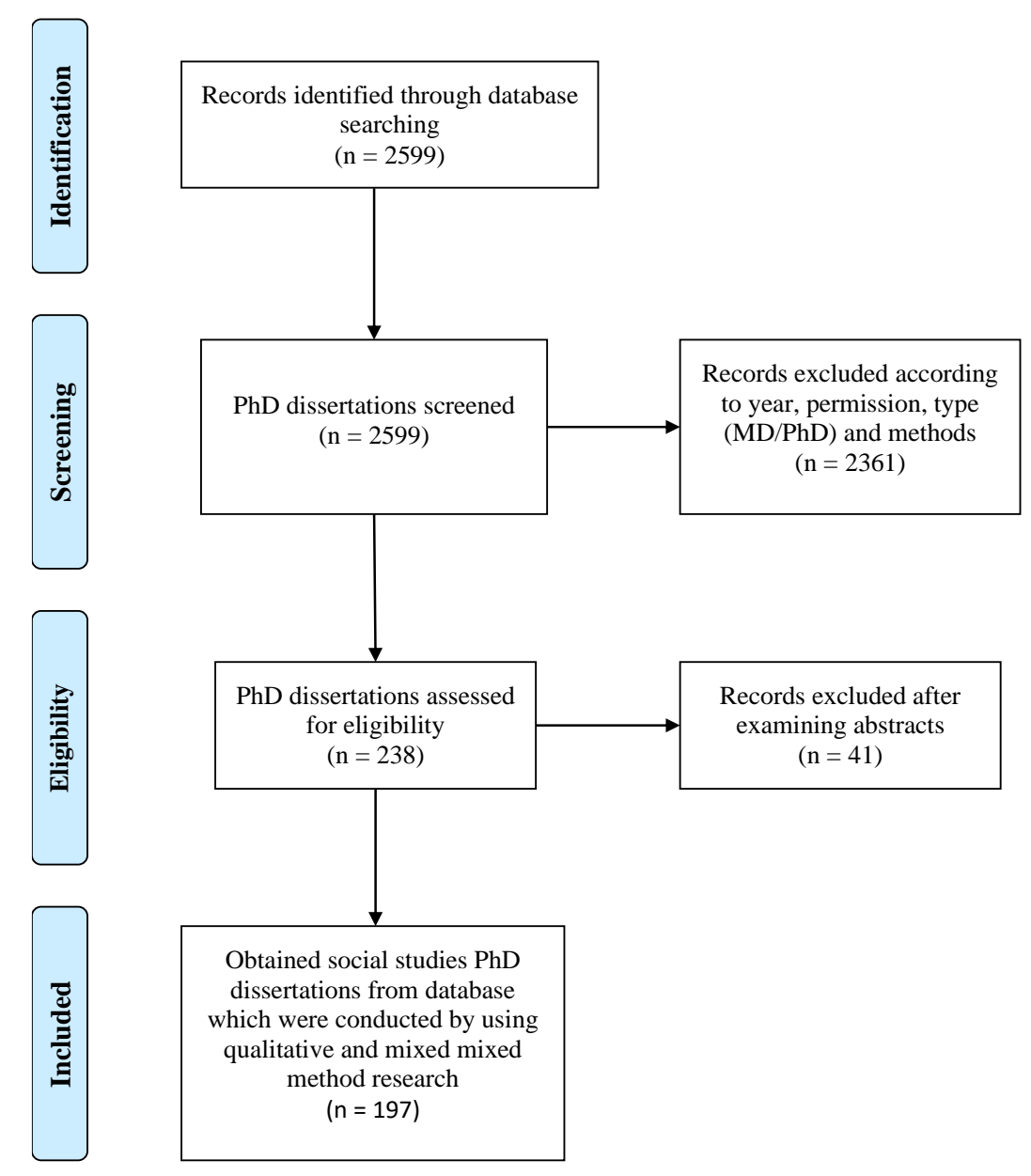

Figure 1. PRISMA flow diagram on the steps in the identification and screening of sources

In order to identify dissertations, I only searched for "social studies" in the National Thesis Database of the National Higher Education Council and found 2599 dissertations. Those dissertations were then eliminated by year, permission for access, dissertation type, research method, and 2361 dissertations was excluded. Moreover, 238 dissertation abstracts were examined and evaluated in detail, and 41 dissertations were excluded due to research methods, study groups, and topic. Finally, I had $197 \mathrm{Ph} . \mathrm{D}$. dissertations to evaluate, which can be seen in Graphic 1 below. 


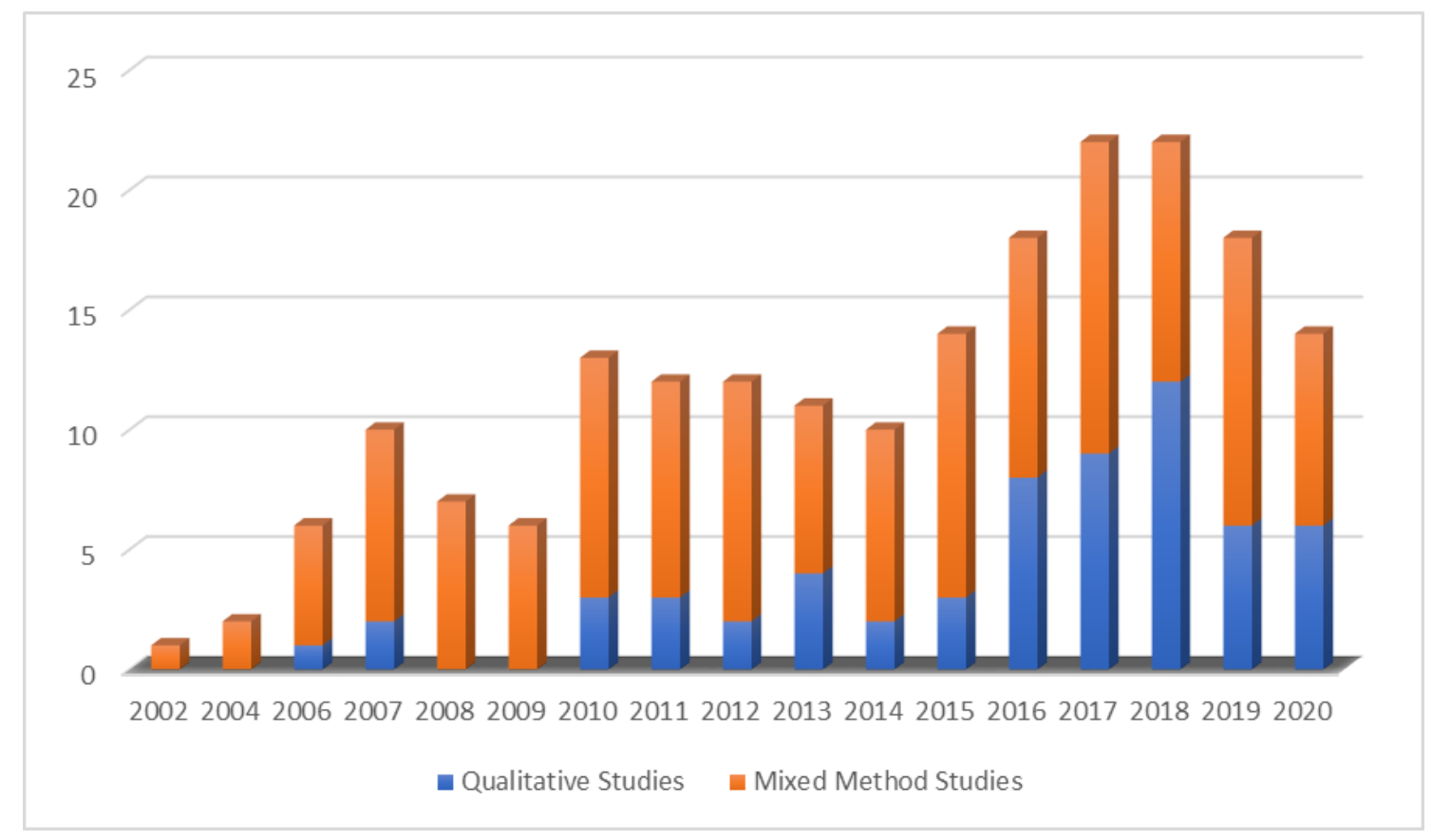

Graphic 1. Methods of dissertations.

As presented in Graphic 1, 137 mixed method and 60 qualitative dissertations were analyzed in the research. No dissertation in 2003 and 2005 were examined due to the research criteria As seen in the graphic, mixed method studies have a big portion comparing with the qualitative studies in the research. Examined Ph.D. dissertation code numbers are presented in Table 2.

Table 2 Dissertation Code Number List

\begin{tabular}{llllllll}
\hline \multicolumn{7}{l}{ Dissertation Code Numbers } \\
\hline 125325 & 250924 & 288267 & 333485 & 395060 & 485895 & 515704 & 547570 \\
145221 & 278406 & 301139 & 333488 & 388245 & 523693 & 522697 & 537370 \\
144332 & 241675 & 298403 & 349961 & 407520 & 481789 & 498753 & 608484 \\
186457 & 278337 & 298544 & 333499 & 418263 & 459564 & 533851 & 538495 \\
187631 & 234459 & 279728 & 349065 & 415878 & 486050 & 486539 & 550987 \\
187967 & 228903 & 290529 & 331716 & 389160 & 477019 & 526098 & 549359 \\
187758 & 278198 & 310790 & 354686 & 498012 & 458531 & 504030 & 603631 \\
191170 & 265734 & 317057 & 384072 & 443518 & 458648 & 527789 & 606536 \\
205766 & 279661 & 317177 & 381627 & 429383 & 471986 & 503701 & 565736 \\
354088 & 258126 & 319985 & 388171 & 434389 & 471805 & 524371 & 605009 \\
205314 & 278157 & 328881 & 356640 & 422969 & 461512 & 526835 & 597337 \\
211673 & 279700 & 306487 & 368290 & 447716 & 463096 & 526483 & 585447 \\
217450 & 265483 & 319663 & 356858 & 429363 & 490667 & 527658 & 618548 \\
210291 & 298446 & 325809 & 383615 & 429625 & 461515 & 531314 & 610550 \\
207141 & 279925 & 349948 & 349042 & 429445 & 486049 & 515042 & 635678 \\
211664 & 279671 & 325801 & 372250 & 450074 & 481781 & 502934 & 647273 \\
207102 & 264176 & 325804 & 418178 & 438240 & 469608 & 534566 & 623835 \\
205306 & 279645 & 317106 & 419404 & 450201 & 469601 & 541681 & 621292 \\
219963 & 279898 & 319657 & 395189 & 429549 & 485956 & 534721 & 630120 \\
226928 & 298642 & 372277 & 421458 & 435392 & 485950 & 621314 & 653037 \\
\hline
\end{tabular}




\begin{tabular}{|c|c|c|c|c|c|c|c|}
\hline 229176 & 298407 & 345301 & 412439 & 441369 & 481748 & 551352 & 623840 \\
\hline 227887 & 279899 & 336126 & 414440 & 511188 & 461451 & 569720 & 616769 \\
\hline 214533 & 279893 & 372298 & 407530 & 429378 & 528026 & 537775 & 627944 \\
\hline 214518 & 290662 & 338529 & 395098 & 426468 & 498754 & 538473 & 636624 \\
\hline 653468 & 643324 & 644501 & 659810 & 612367 & & & \\
\hline
\end{tabular}

\section{Data analysis}

In this study, I used deductive coding and analysis approach to analyze the documents. Deductive approach involves creating codes and themes in the data analysis (Harding, 2013). I used Guba's (1981) trustworthiness strategies which provide a common framework in the literature, to analyze dissertations. In this framework, several strategies were recommended to establish trustworthiness in qualitative research and studies (Lincoln and Guba, 1986). Guba (1981) also developed four criteria: credibility, transferability, dependability, and conformability, corresponding to internal validity, external validity, reliability, and objectivity in quantitative research. However, I only used the strategies, not the criteria, as some strategies included more than one criterion. For example, triangulation was clarified under both credibility and confirmability (Guba, 1981). The reflexivity strategy was also clarified under all four criteria (Lincoln and Guba, 1986). It might result in ambiguity and overlap in data analysis.

On the other hand, some scholars heavily criticized those criteria terms (e.g., Leninger, 1994; Sandelowski, 1993; Sadik, 2019). They claimed that trying to make connections between reliability and validity in qualitative studies does not make sense due to the assumptions of interpretivist paradigm. According to the interpretivism, it is believed that there are multiple constructed realities in the universe and these realities are not repeated or reflects in the same way in everywhere and every time. If so, we naturally can not determine the valid and reliable information. In other words, we can not measure what we think we are in qualitative studies (Kerlinger, 1964, as cited in Sadik, 2019). Hence, using validity and reliability terms may cause dilemmas in terms of ontology and epistemology of the research. However, most of scholars who criticize these terms agree with the trustworthiness strategies. Therefore, I preferred to use only strategies as themes to prevent potential confusion and ambiguity in the data analysis.

In conclusion, the study included the themes of persistent observation, prolonged engagement, triangulation, peer debriefing, negative case analysis, referential adequacy, member checking, thick description, audit trail, external audit, and reflexivity strategies. I did not choose the "overlap methods" strategy due to the possible ambiguities. As I mentioned above, I included dissertations using mixed methods. The reasons for using mixed methods and overlap methods strategy are pretty similar. Since the mixed-method approaches have appeared in the 1980 s, it is quite possible to label them as an overlap methods strategy instead of a mixed method.

I used Excel software to analyze dissertations. Excel document included the number, year, type, sample, research design, data collection tools, and trustworthiness strategies. It was also examined whether there was at least one trustworthiness strategy in those dissertations.

I used external audit strategy to establish the trustworthiness of the study. I discussed research problem, data analysis and findings of the study with two experts. Both of them have Ph.D. 
degrees and experience in qualitative research. One of them has Ph.D. degree in Educational Leadership and the other has $\mathrm{PhD}$ degree in primary education.

\section{Findings}

One of the important findings of this study is about the application of trustworthiness strategies in the dissertations. In this sense, it was concluded that no trustworthiness strategies were used or reported in 83 out of 197 dissertations. In other words, almost half of $\mathrm{PhD}$ dissertations where researchers obtained and analyzed qualitative data are not rigorous enough in terms of establishing trustworthiness. When I examined qualitative and mixed method studies separately, nearly the same results appeared in the mixed method studies as presented in Graphic 2.

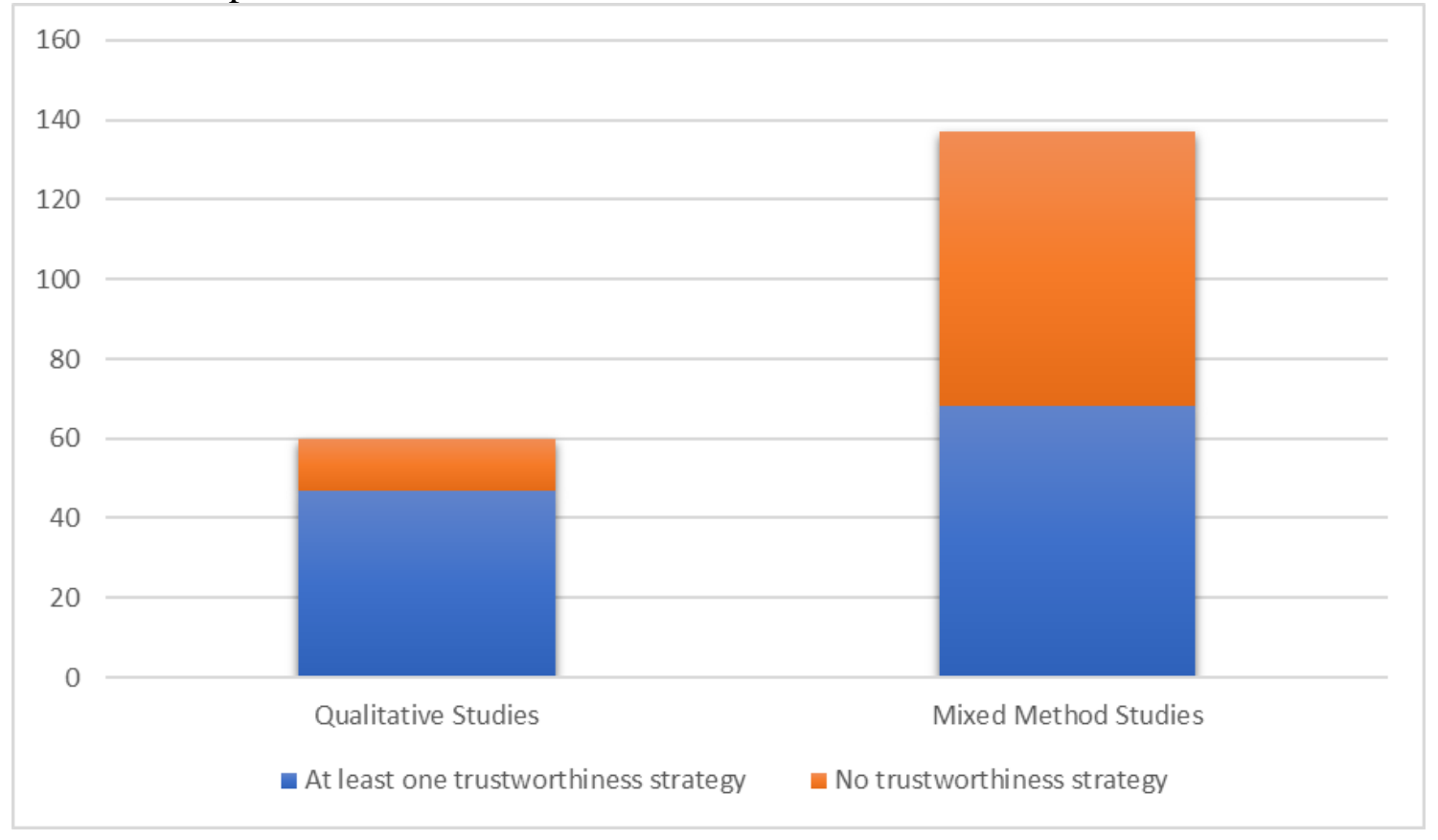

Graphic 2. The dissertations in which trustworthiness strategies were used or reported

As shown in Graphic 2, almost half of the dissertations using mixed methods were not rigorous enough in terms of establishing trustworthiness. On the other hand, it is seen that most of dissertations using qualitative research methods had at least one trustworthiness strategy.

Besides, I examined dissertations by year to understand the awareness of trustworthiness in the studies. The findings are presented in Graphic 3. 


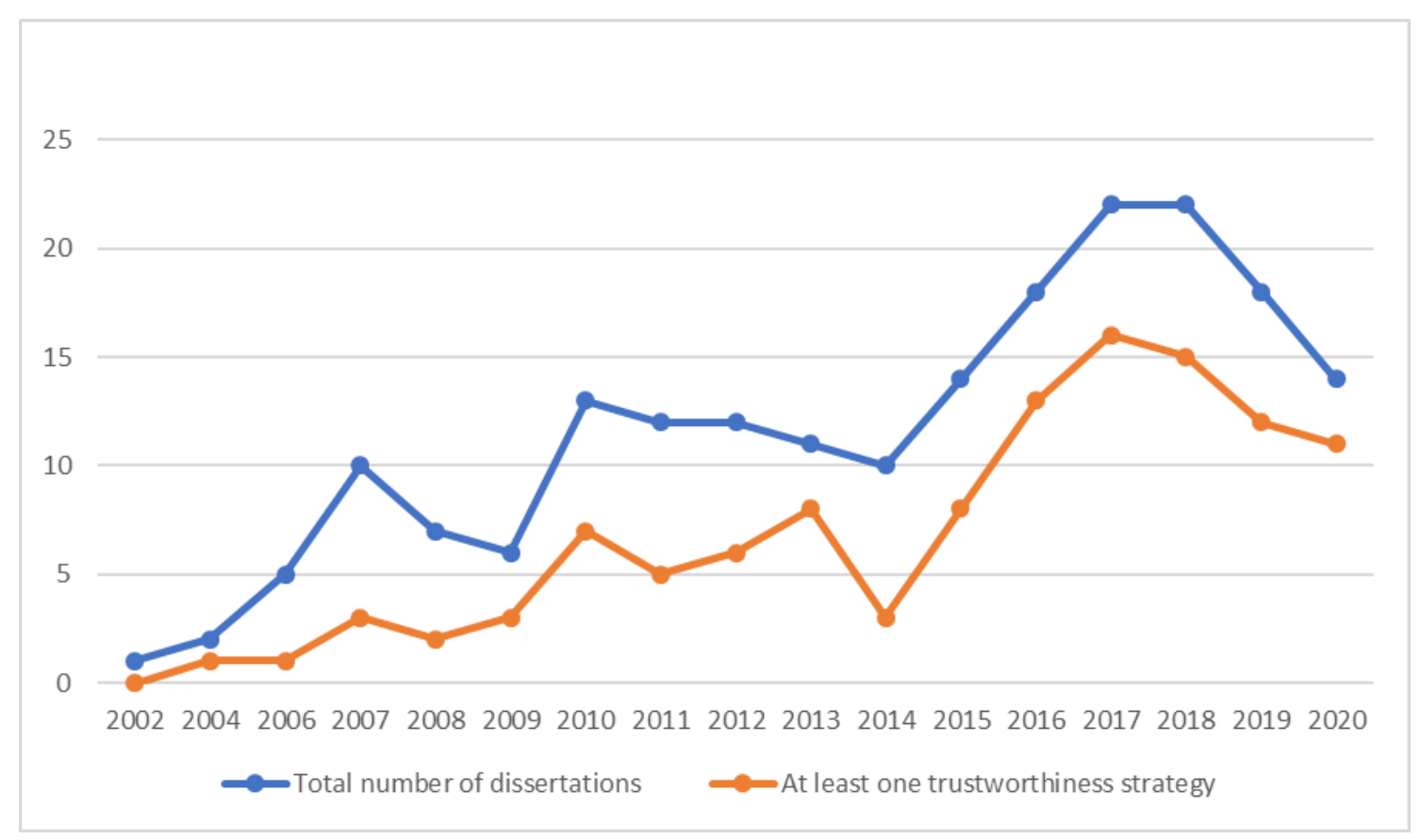

Graphic 3. The analysis of trustworthiness in dissertations by year

It is expected that the awareness of the rigor of qualitative research might be raised in the last years. However Graphic 3 do not show this expectation. Because as it is seen in the Graphic 3 , the distinction between dissertations in which at least one trustworthiness strategy was used and dissertations in which any trustworthiness strategy was not used looks the same in all years except 2007 and 2011.

Another critical finding is about the preferred terminology. In most studies using at least one trustworthiness strategy, researchers reported what they had done to ensure trustworthiness under the section of "validity and reliability". These results are presented in Table 3.

Table 3. The use of terminology in dissertations

\begin{tabular}{lc}
\hline Terminology & Number of dissertations \\
\hline Validity and reliability & 95 \\
Trustworthiness & 18 \\
Scientificness of the research & 1 \\
\hline
\end{tabular}

As shown in Table 3, the procedures about trustworthiness strategies are reported as "validity" and "reliability" in most of the dissertations. Although most of researchers prefer to use these terms, they explained about trustworthiness strategies under these headings. However, when reports under these headings are examined, a contradiction appears about the terminology. It is noteworthy that although researchers prefer to use "validity" and "reliability" terms as sub-headings in the method section, interestingly they literally stated that "validity and reliability terms are not used in qualitative studies". But, if these terms are not used in qualitative research, why researchers use these terms as sub-headings in order to explain the trustworthiness of the study? In other words, even though most of researchers are aware of appropriate terminology, they preferred to use the incorrect one. Consequently, this contradiction leads to bias in the dissertations.

The other important finding is about the most frequently used trustworthiness strategies. The 
results are presented in Table 4.

Table 4. The most frequently used trustworthiness strategies

\begin{tabular}{|c|c|c|}
\hline \multicolumn{2}{|c|}{ Trustworthiness strategies } & Number of dissertations \\
\hline \multicolumn{2}{|c|}{ Prolonged Engagement } & 35 \\
\hline \multicolumn{2}{|c|}{ Persistent Observation } & 9 \\
\hline & Source triangulation & 24 \\
\hline \multirow{3}{*}{ Triangulation } & Data triangulation & 55 \\
\hline & Theory triangulation & 1 \\
\hline & Analyst triangulation & 1 \\
\hline \multicolumn{2}{|c|}{ Peer Debriefing } & 67 \\
\hline \multicolumn{2}{|c|}{ Negative Case Analysis } & 0 \\
\hline \multicolumn{2}{|c|}{ Referential Adequacy } & 0 \\
\hline \multicolumn{2}{|c|}{ Member Checking } & 21 \\
\hline \multicolumn{2}{|c|}{ Thick Description } & 53 \\
\hline \multicolumn{2}{|c|}{ Audit Trail (Inquiry Audit) } & 5 \\
\hline \multicolumn{2}{|l|}{ External Audit } & 68 \\
\hline \multicolumn{2}{|c|}{ Stepwise Replication } & 0 \\
\hline \multicolumn{2}{|l|}{ Reflexivity } & 21 \\
\hline
\end{tabular}

As shown in Table 4, external audit and peer-debriefing strategies were mainly reported to establish the studies' trustworthiness. On the contrary, stepwise replication, overlap methods, negative case analysis, and referential adequacy were not reported in any dissertations. Theory and analyst triangulation strategies were reported only in one dissertation, but the researcher did not explain how s/he applied this strategy. Also, when peer debriefing strategies examined, it was revealed that researchers mostly preferred inter-coder reliability formulate, which was proposed by Miles and Huberman (1994). Lastly, it was seen that Cohen Kappa Value was reported as a trustworthiness strategy in a few dissertations.

\section{Results, Discussion, and Implications}

In daily life, people wonder and search for various things. For instance, children attempt to investigate what they wonder, or journalists try to reach specific results from different sources. Similarly, scientists conduct their research by employing several methods and share their results systematically. However, there are distinct differences between scientific inquiry and any other type of inquiries. Rigor is one of the most critical elements which distinguish scientific inquiry from other types of inquiry. In other words, what makes research "scientific" is the scientific principles and rigor. Because "without rigor, research is worthless, it is just a fiction, and has no benefit" (Morse et al., 2002).

Both qualitative and quantitative research have unique scientific rigor procedures. Trustworthiness is one of the essential components of rigor in qualitative research. However, there is no consensus on establishing rigor of qualitative research in the literature, which leads to much confusion about this issue. Although there is no strong consensus about the qualitative studies' trustworthiness, Guba's (1981) trustworthiness framework has been accepted by many qualitative researchers. So, I considered and used this framework to examine how researchers ensure trustworthiness in their social studies education dissertations.

It was revealed that almost half of the dissertations did not include any trustworthiness strategies. In other words, half of the Ph.D. dissertations were not rigorous enough in terms of 
trustworthiness. Berkovich and Grinshtain also found that at least one or none of trustworthiness strategies were reported in the nearly $\% 82$ of 321 studies that they were examined in the field of qualitative educational administration, management and leadership research. Similarly, Dere and Gökçınar (2020) determined that no trustworthiness strategy reported or used 44 out of 118 dissertations about social studies textbooks. In addition to these, it was also found that the difference between the total number of dissertations using qualitative research methods and the dissertations including at least one trustworthiness strategy is almost the same in almost all years. However, it is expected that the awareness of trustworthiness might have increased in recent years, but interestingly, the findings showed that it has not increased even in the last years. All these studies suggest that trustworthiness issue is quite worrying in the qualitative research. In other words, as Krefting (1990) emphasized, little attention is paid to trustworthiness despite the increasing interest in qualitative research.

Moreover, I found that the number of mixed-method studies in which any trustworthiness strategy was not used was higher than the number of qualitative studies using no trustworthiness strategy. In this sense, the dissertations using mixed methods were more problematic than the dissertations conducted by employing qualitative research methods in terms of trustworthiness. Üzümcü (2016) also found that while researchers reported information about the validity and reliability in dissertations which were conducted by employing mixed method research in educational sciences, they did not give any information about the trustworthiness of the study. These results are quite worrying since half of the dissertations, especially those conducted by employing mixed-method research, included certain doubts about ensuring the study rigor or trustworthiness.

Another significant result was about the terminology. I found that several terms were reported to ensure the study's trustworthiness in dissertations in which at least one trustworthiness strategy was used. "Validity and reliability" terms were mostly preferred to report the trustworthiness in dissertations. Besides, the term "trustworthiness" was reported in quite limited dissertations. Similarly, Morse et al. (2002) stated that reliability and validity terms have yet been used in qualitative studies, especially in Great Britain and Europe. However, if it is believed that the paradigm of qualitative research methods is different from the positivist paradigm, unique terms should be used for qualitative research. That is, unique terms and expressions should be preferred in every research paradigm as every paradigm generates characteristic terms and concepts that distinguish it from others. Accordingly, scholars should use appropriate terms following paradigms. (Murphy and Yielder, 2009). Many scholars suggest not to use positivist terms such as validity and reliability to explain the rigor of qualitative studies (Carcary, 2009; Lincoln and Guba, 1985; Morse et al., 2002; Shenton, 2004; Williams and Morrow, 2009).

I tried to reveal the most common trustworthiness strategies in dissertations in social studies education. In this regard, peer debriefing, external audit, thick description, and data triangulation were the most frequently used or reported trustworthiness strategies in dissertations. Similarly, Türkkan, Yolcu and Karataş (2019) determined that peer debriefing, external audit, triangulation, thick description and prolonged engagement strategies were mostly used strategies in 118 educational sciences dissertations in which action research was employed. Dere and Gökçınar (2020) also found that external audit and peer debriefing are mostly used trustworthiness strategies in 114 master and $8 \mathrm{Ph} . \mathrm{D}$. dissertations which are about social studies textbooks. Besides, Balat, Kayalı, Gündüz and Göktaş (2019) and Barusch, Gringeri and George (2011) stated that triangulation was one of the mostly used 
trustworthiness strategy in the field of qualitative educational technology and qualitative social work studies. In addition to all these, Berkovich and Grinshtain (2021) also found that member checking was one of the mostly used trustworthiness strategy in the qualitative educational administration, management and leadership research In conclusion, it could be asserted that researchers mostly try to ensure trustworthiness of dissertations by employing peer debriefing, external audit, triangulation, thick description, member checking and prolonged engagement strategies.

Besides, the intercoder reliability proposed by Miles and Huberman (1994), one of the most common strategies, was acknowledged as peer debriefing trustworthiness strategy in the current study. Similarly, Conner and Joffe (2020) noted that search for the keywords "qualitative" and "intercoder reliability" or "inter-coder reliability" yielded over 1,000 results on Scopus, International Journal of Qualitative Method, and over 16,000 on Google Scholar in only 2018. Likewise, Lombard, Snyder-Duch, and Bracken (2002) indicated inter-coder reliability was reported in $69 \%$ of mass communication research. Üzümcü (2016) also found that the inter-coder reliability was the most used trustworthiness strategy in dissertations that were conducted in the field of educational sciences between 2013 and 2015. Although it is highly accepted in the literature and used by many researchers, inter-coder reliability is still a controversial issue for qualitative researchers, arguing that it is inappropriate for qualitative analysis (O'Conner and Joffe, 2020). I also agree with these critics that inter-coder reliability does not fit with the nature of qualitative research because it is a formula, and researchers evaluate the trustworthiness considering the reliability value, which should be higher than $80 \%$. However, if it is measured $79 \%$, should we conclude that "the research is weak" in terms of rigor? Or vice versa. I think this result shows that numbers sound more trusty regardless of the paradigm and the methods based on the paradigms.

On the other hand, it was determined that negative case analysis, stepwise replication, and referential adequacy strategies were not used or reported in any dissertations. Theory and analyst triangulation strategies were reported in only one dissertation, but the researcher did not clarify the application process in the research. It was also seen that the audit trail strategy was used or reported only a few dissertations. Similarly, Carcary (2009) indicated that although an audit trail is beneficial to ensure trustworthiness, it is rarely used in the literature. Berkovich and Grinshtain (2021) also found that negative case analysis and persistent observation were used in the quite limited number of qualitative educational administration, management and leadership research. Besides, Barusch, Gringeri and Georger determined that negative case analysis was least common strategy in the qualitative social work research. Undoubtedly, all trustworthiness strategies can not be used in a research design like document analysis (Krefting, 1990). For instance, member checking could not be practical for postmodern philosophies such as feminism and critical theory in which the researchers' experience becomes a part of the study data (Morse et al., 2002). However, it should be questioned why these trustworthiness strategies were not used or reported even in one dissertation among 197 dissertations in social studies education. It can be inferred that researchers might not be aware of all trustworthiness strategies in the literature or undermine some strategies such as negative case analysis, stepwise replication, referential adequacy and persistent observation.

The following implications were made considering the study results and findings: 
- Supervisors and academicians should emphasize the rigor and trustworthiness aspects of qualitative research.

- Ph.D. candidates should have enough knowledge and skills to establish trustworthiness in qualitative research, and they should gain experience by researching with their supervisors during the graduate education.

- Supervisors should have enough knowledge and skills to establish trustworthiness in qualitative research. They should pay attention to the trustworthiness and follow the latest developments on this issue.

- The monitoring and defense committee should elaborately evaluate and discuss the method sections in dissertations.

- Seminars or panels could be organized for graduate students to raise awareness about establishing trustworthiness in qualitative research.

\section{Limitation of the study}

As it is expected to report the study rigor in the method section, this study is limited to the information which are reported only in the method section of dissertations. In this case, the question of what would happen if the researchers wrote the care of the research in another section may come to mind. In the case both of right or wrong, all answers show researchers' awareness about the trustworthiness of a study. In other words, if researchers recognize the importance of trustworthiness in qualitative research, they should report it in the method section. Otherwise, it shows a lack of awareness about the study rigor.

\section{References}

Akpınar, M., \& Kaymakçı, S. (2012). A comparative view to Turkish social studies education's general goal. Kastamonu Education Journal, 20(2), 605-626.

Amankwaa, L. (2016). Creating protocols for trustworthiness in qualitative research. Journal of Cultural Diversity, 23 (3), 121-127.

Balat, Ş., Kayal1, B., Gündüz, A., \& Göktaş, Y. (2019, April). Doktora tezlerinde alınan geçerlik ve güvenirlik önlemleri [Validity and reliability in Ph.D. dissertations]. In $\mathrm{H}$. Akyol \& A. Y1lmaz (Chairs), the $28^{\text {th }}$ International Conference on Educational Sciences. Hacettepe University, Ankara.

Barusch, A., Gringeri, C., \& George, M. (2011). Rigor in qualitative social work research: a review of strategies used in published articles. Social Work Research, 35(1), 11-19.

Berkovich, I., \& Grinshtain, Y. (2021). A review of rigor and ethics in qualitative educational administration, management, and leadership research articles published in 1999-2018. Leadership \& Policy in Schools. Advance online publication. doi: 10.1080/15700763.2021.1931349

Bowen, G. A. (2009). Document analysis as a qualitative research method. Qualitative Research Journal. 9(2), 27-40.

Canbulat, T., Avc1, G., \& Sipahi, S. (2016). Abd ve Kanada ve Türkiye'de sosyal bilgiler eğitimi alanındaki tezlerin değerlendirilmesi [The evaluation of the thesis in the field of social studies in the USA and Canada]. Kırşehir Faculty of Education Journal, 17(2), 351-370.

Carcary, M. (2009). The research audit trail--enhancing trustworthiness in qualitative inquiry. Electronic Journal of Business Research Methods, 7(1), 11-24.

Chapin, J. R. (1974). Social studies dissertations: 1969-1973. ERIC Clearing House for Social Studies/Social Sciences, 
Cooley, A. (2013). Qualitative education research: the origins, debates, and politics of creating knowledge. Educational Studies: A Journal of the American Educational Studies Association. 49(3), 247-262.

Creswell, JW. (1998). Qualitative inquiry and research design choosing among five traditions. CA: Sage Publications.

Curtin, M., \& Fossey, E. (2007). Appraising the trustworthiness of qualitative studies: Guidelines for occupational therapists. Australian Occupational Therapy Journal, 54, 88-94.

Çayır, K., \& Gürkaynak, İ. (2007). The state of citizenship education in Turkey: Past and present. The Journal of Social Science Education, 6(2), 50-58.

Dere, İ., \& Gökçınar, B. (2020). Türkiye'de sosyal bilgiler eğitiminde ders kitaplarıyla ilgili hazırlanan tezlerin egilimleri (2001-2020) [the trends of dissertations written on the textbooks of social studies education in Turkey (2001-2020)]. Uşak University Journal of Educational Research, 7(1), 51-66.

Dilek, A., Baysan, S., \& Öztürk, A. A. (2018). Türkiye'de sosyal bilgiler eğitimi üzerine yapılan yüksek lisans tezleri: Bir içerik analizi çalışması [Social studies education master thesis in Turkey: A content analysis study]. Turkish Journal of Social Research, 22(2), 581-602.

Dhand, H. (1984). An analysis of Canadian thesis in social studies education. History and Social Science Teacher, 19(3), 160-164.

Dhand, H. (1988). Analysis of Canadian thesis in social studies education, 1981-1985. History and Social Science Teacher, 23(2), 99-102.

Duman, A., \& İnel, Y. (2019). Review of master's theses in the field of social studies education between 2008 and 2014. Universal Journal of Educational Research, 7(1), 66-73.

Elo, S., Kaariainen, M., Kanste, O, Pölkki, T., Utriainen, K., \& Kyngas, H. (2014). Qualitative content analysis: A focus on trustworthiness. Sage Open, 4(1), 1-10.

Gross, R. E., \& De La Cruz, L. (1971). Social studies dissertation 1963-1969.ERIC Clearing House for Social Studies/Social Sciences Education,

Guba, E. G. (1981). Criteria for assessing the trustworthiness of naturalistic inquiries. Educational Communication and Technology, 29(2), 75-91.

Gunawan, J. (2015). Ensuring trustworthiness in qualitative research. Belitung Nursing Journal, 1(1), 10-11.

Güleç, S., \& Hüdavendigar, M. N. (2020). Sosyal bilgiler eğitimi alaninda okuryazarlik becerisi başliğinda yapilan lisansüstü tezlerin incelenmesi [Examination of the postgraduate theses prepared under the title of literacy skills in the field of social studies education]. International Journal of Humanities and Art Researches, 3(3), 2436.

Haçat Oğuz, S., \& Demir, F. B. (2018). Sosyal bilgiler eğitimi üzerine yapılan doktora tezlerinin değerlendirilmesi [Evaluation of the doctoral dissertations conducted on social studies education (2002-2018)]. International Journal of Eurasian Researches, 6(15), 948-973.

Harding, J. (2013). Qualitative data analysis from start to finish. Sage: London.

Hepburn, M. A., \& Dahler, A. (1985). An Overview of social studies dissertations, 19771982. Theory \& Research in Social Education, 13(2), 73-82.

Huang, C., Yang, C., Wang, S., Wu, W., Su, J., \& Liang, C. (2020). Evolution of topics in education research: a systematic review using bibliometric analysis. Educational Review, 72(3), 281-297. 
Karakuş, S. (2020). Türkiye'de sosyal bilgiler eğitiminde kavramlar konusunda yapılan yüksek lisans ve doktora tezlerinin incelenmesi [An examine master thesis and Phd dissertations conducted in the field of the concepts in social studies education in Turkey]. Academia Journal of Educational Research, 5(1), 61-76.

Kayaalp, F., \& Karameşe, E. N. (2020). Türkiye'de sosyal bilgiler eğitimi kapsamında hazırlanan "vatandaşlık" konulu lisansüstü tezlerdeki eğilimler [Trends in Graduate Theses on "Citizenship" in the fieldof Social Studies Education in Turkey]. Kırşehir Faculty of Education Journal, 21(1), 744-786.

Krefting, L. (1990). Rigor in qualitative research: The assessment of trustworthiness. The American Journal of Occupational Therapy, 45(3), 214-222.

Leninger, M. (1994). Evaluation criteria and critique of qualitative research studies. J. M. Morse (Ed.) In Critical issues in qualitative research methods. Newbury Park: Sage Publications.

Lietz, C. A., Langer, C. L., \& Furman, R. (2006). Establishing trustworthiness in qualitative research in social work: Implications from a study regarding spirituality. Qualitative Social Work, 5(4), 441-458.

Lincoln, Y. S., \& Guba, E. G. (1985). Establishing trustworthiness. Naturalistic Inquiry, 289(331), 289-327.

Lombard, M., Snyder-Duch, J., \& Bracken, C. C. (2002). Content analysis in mass communication: Assessment and reporting of intercoder reliability. Human Communication Research, 28(4), 587-604.

Miles, M. B., \& Huberman, A. M. (1994). Qualitative data analysis: An expanded sourcebook. Los Angeles: Sage.

Morse, J. M. (2002). Verification strategies for establishing reliability and validity in qualitative research. International Journal of Qualitative Methods, 1(2), 13-22.

Morse, J. M. (2015). Critical analysis of strategies for determining rigor in qualitative inquiry. Qualitative Health Research, 25(9), 1212-1222.

Murphy, F. J., \& Yielder, J. (2009). Establishing rigor in qualitative radiography research. Radiography, 16(1), 62-67.

Nowell, L. S., Norris, J. M., White, D. E., \& Moules, N. J. (2017). Thematic analysis: Striving to meet the trustworthiness criteria. International Journal of Qualitative Methods, 16(1), 1609406917733847.

O'Connor, C., \& Joffe, H. (2020). Intercoder reliability in qualitative research: debates and practical guidelines. International Journal of Qualitative Methods, 19, 1-13. doi: 10.1177/1609406919899220.

O'Donoghue, T. (2007). Planning your qualitative research project: An introduction to interpretivist research in education. Abingdon: Routledge.

Onwuegbuzie, A. J., \& Daniel, L. G. (2003). Typology of analytical and interpretational errors in quantitative and qualitative educational research. Current Issues in Education, 6(2), 1-33.

Öner, G., \& Öner, D. (2017). Sosyal bilgiler eğitiminde coğrafya konuları üzerine yapılmış lisansüstü tezlere yönelik bir analiz ve bibliyografya çalışması [An analysis and bibliography study of graduate theses written on geography subjects in social studies education]. Boğaziçi University Journal of Education, 34(2), 13-34.

Öztürk, C. (2012). Sosyal bilgiler: Toplumsal yaşama disiplinlerarası bir bakış. [Social studies: An interdisciplinary view of social life]. C. Öztürk (Ed.) In sosyal bilgiler ögretimi [social studies teaching] (p. 2-31). Ankara: Pegem Akademi.

Patton, M. Q. (200). Qualitative research \& evaluation methods. California: Sage. 
Saban, A., Koçbeker Eid, B. N., Saban, A., Alan, S., Doğru, S., Ege, İ., Arslantaş, S., Çınar, D., \& Tunç, P. (2010). Eğitimbilim alanında nitel araştırma metodolojisi ile gerçekleştirilen makalelerin analiz edilmesi [An analysis of educational articles conducted by the qualitative research methodology]. Ahmet Keleşoğlu Faculty of Education Journal, 30, 125-142.

Sadik, O. (2019). A discussion of the concepts of validity and reliability in qualitative and quantitative research. Mediterranean Journal of Educational Research, 13(28), 145156. doi: 10.29329/mjer.2019.202.8.

Sağdıç, M. (2019). Türkiye'de sosyal bilgiler eğitiminde disiplinlerarası öğretim yaklaşımının tarihsel gelişimi [Historical development of interdisciplinary teaching approaches in social studies education in Turkey]. Journal of History Culture and Art Research, 8(2), 390-403. doi:10.7596/taksad.v8i2.2121

Sandelowski, M. (1993). Rigor or rigor mortis: the problem of rigor in qualitative research. Advances in Nursing Science, 16(2), 1-8.

Saxe, D. W., Jackson, M. L., \& Mraz, M. (1994). Dissertation research in social studies 19811991.

Shenton, A. K. (2004). Strategies for ensuring trustworthiness in qualitative research projects. Education for Information, 22(2), 63-75.

Şahin, M. D., \& Öztürk, G. (2019). Mixed method research: Theoretical foundations, designs and its use in educational research. International Journal of Contemporary Educational Research, 6(2), 301-310.

Şahin, M., Yıldız, D. G., \& Duman, R. (2011). Türkiye'deki sosyal bilgiler eğitimi tezleri üzerine bir değerlendirme [An evaluation of the theses on social studies education in Turkey]. Journal of Social Studies Education Research, 2(2), 96-121.

Tarman, B., Acun, İ., \& Yüksel, Z. (2010). Sosyal bilgiler eğitimi alanındaki tezlerin degerlendirilmesi [Evaluation of thesis in the field of social studies education in Turkey]. Gaziantep University Journal of Social Sciences, 9(3), 725-746.

Türkkan, B. T., Yolcu, E,. \& Karataş, T. (2019). Türkiye'de eğitim bilimleri alanında eylem araştırması içeren doktora tezlerinin incelenmesi [Analysis of doctoral dissertations including action research in the field of educational sciences in Turkey]. Journal of Bayburt Education Faculty, 14(28), 501-524.

Twining, P., Heller, R. S., Nussbaum, M., \& Tsai, C. C. (2017). Some guidance on conducting and reporting qualitative studies. Computers \& Education, 106, A1-A9.

Üzümcü, Ö. (2016). Nitel araştırma yöntemine sahip tezlerin bazı değişkenler açısından incelenmesi [Investigating thesis made by using qualitative research methods in terms of some variables]. The Journal of Academic Social Science (Asos Journal), 4(32), 327-340.

Wrubel, P. R., \& Ratliff, R. (1978). Social studies dissertations: 1973-1976. ERIC Clearing House for Social Studies/Social Sciences. 
APPENDIX A

\section{Data Collection Tool}

\begin{tabular}{|c|c|c|c|c|c|c|c|c|c|c|c|c|c|c|c|c|c|}
\hline & & & & \multicolumn{14}{|c|}{ Trustworthiness Strategies } \\
\hline & & & & \multicolumn{6}{|c|}{ Triangulation } & & & & & & & & \\
\hline $\begin{array}{c}\begin{array}{c}\text { Dissertatioum } \\
\text { Code } \\
\text { Number }\end{array} \\
\end{array}$ & Year & \begin{tabular}{|c|} 
Method \\
(Mixed/Qualit \\
ative)
\end{tabular} & Terminology & $\begin{array}{c}\text { Prolonged } \\
\text { Engagement }\end{array}$ & \begin{tabular}{|c|} 
Persistent \\
Observation
\end{tabular} & \begin{tabular}{|c|} 
Source \\
Triangulation \\
\end{tabular} & \begin{tabular}{|c|} 
Data \\
Triangulation
\end{tabular} & \begin{tabular}{|c|} 
Theory \\
Triangulation \\
\end{tabular} & $\begin{array}{c}\text { Analyst } \\
\text { Triangulation }\end{array}$ & $\begin{array}{c}\text { Peer } \\
\text { Debriefing }\end{array}$ & $\begin{array}{c}\text { Negative } \\
\text { Case } \\
\text { Analysis }\end{array}$ & \begin{tabular}{|c|} 
Referential \\
Adequacy
\end{tabular} & $\begin{array}{l}\text { Member } \\
\text { Checking }\end{array}$ & $\begin{array}{c}\text { Thick } \\
\text { Discription } \\
\end{array}$ & $\begin{array}{c}\text { Audit Trial } \\
\text { (Inquiry Audit) }\end{array}$ & $\begin{array}{c}\text { External } \\
\text { Audit } \\
\end{array}$ & Reflexivity \\
\hline & & & & & & & & & & & & & & & & & \\
\hline & & & & & & & & & & & & & & & & & \\
\hline
\end{tabular}

